\title{
Analisis Kestabilan Model Matematika Penyebaran Penyakit Demam Berdarah dengan Pengaruh Fogging
}

\author{
Siti Windawati ${ }^{1 *}$, Ali Shodiqin ${ }^{2}$, Aurora Nur Aini ${ }^{3}$ \\ 1,2,3 Universitas PGRI Semarang \\ *siti.windawati@gmail.com
}

\begin{abstract}
ABSTRAK
Penyakit demam berdarah adalah penyakit infeksi yang disebabkan oleh virus dengue yang ditularkan oleh nyamuk Aedes Aegypty melalui gigitan nyamuk betina yang terinfeksi. Penyakit demam berdarah merupakan salah satu masalah kesehatan utama di Indonesia. Pencegahan utama untuk mengatasi demam berdarah adalah pengendalian nyamuk yang merupakan vektor penyakit. Salah satunya adalah pemberantasan nyamuk dengan fogging. Pada penelitian ini dibahas tentang model matematika penyebaran penyakit demam berdarah dengan pengaruh fogging. Selanjutnya dari model matematika ditentukan titik ekuilibrium bebas penyakit dan titik ekuilibrium endemik. Kemudian dilakukan analisis kestabilan titik ekuilibrium bebas penyakit dan titik ekuilibrium endemik dan simulasi numerik kestabilan titik ekuilibrium dan pengaruh fogging terhadap penyebaran penyakit demam berdarah dengan menggunakan software Matlab. Berdasarkan hasil analisis, titik ekuilibrium bebas penyakit stabil asimtotik lokal jika bilangan reproduksi dasar kurang dari satu dan titik ekuilibrium endemik stabil asimtotik lokal jika bilangan reproduksi dasar lebih dari satu. Hasil simulasi pengaruh fogging terhadap penyebaran penyakit demam berdarah menunjukkan dengan adanya laju fogging, maka rata-rata kasus infeksi sekunder yang dihasilkan oleh individu terinfeksi jumlahnya sedikit.
\end{abstract}

Kata kunci: demam berdarah, fogging, titik ekuilibrium, bilangan reproduksi dasar.

ABSTRACT

Dengue fever is an infectious disease caused by dengue virus that is transmitted by the Aedes Aegypty mosquito through the bite of an infected female mosquito. Dengue fever is one of the main health problems in Indonesia. The main prevention to overcome dengue fever is mosquito control which is a vector of disease. One of them is the eradication of mosquitoes by fogging. This research discusses the mathematical model of the spread of dengue fever with the influence of fogging. Furthermore, from the mathematical model determined the disease-free equilibrium point and endemic equilibrium point. Then the stability of the disease-free equilibrium point and endemic equilibrium point stability and numerical simulation of the stability of the equilibrium point and the effect of fogging on the spread of dengue fever using Matlab software were performed. Based on the results of the analysis, the disease-free local asymptotic stable equilibrium point if the base reproduction number is less than one and the endemic equilibrium point is stable asymptotic locally if the base reproduction number is more than one. The results of the simulation of the effect of fogging on the spread of dengue fever show that with the rate of fogging, the average number of secondary infections produced by infected individuals is small.

Keywords: dengue fever, fogging, equilibrium point, basic reproduction numbers. 


\section{PENDAHULUAN}

Demam berdarah dengue (DBD) adalah penyakit infeksi yang disebabkan oleh virus dengue yang mengakibatkan demam akut dan ditularkan oleh nyamuk Aedes Aegypti (Arsin, 2013). Virus dengue termasuk kelompok B Arthropod Borne Virus (Arboviroses) yang sekarang dikenal sebagai genus Flavivirus, famili Flaviviridae, dan mempunyai empat jenis serotipe, yaitu DEN-1, DEN-2, DEN-3, DEN-4 (Irianto, 2014). Infeksi oleh salah satu serotipe akan menimbulkan kekebalan terhadap serotipe yang bersangkutan tetapi tidak untuk serotipe yang lain (Masriadi, 2017).

Penyakit demam berdarah masih merupakan salah satu masalah kesehatan masyarakat yang utama di Indonesia. Menurut data WHO, Asia Pasifik menanggung 75 persen dari beban dengue di dunia antara tahun 2004 dan 2010, sementara Indonesia dilaporkan sebagai negara ke-2 dengan kasus DBD terbesar diantara 30 negara wilayah endemis (Pusat Data dan Informasi Kementerian Kesehatan RI, 2017). Berdasarkan data Kementerian Kesehatan RI (2019) secara nasional jumlah kasus demam berdarah hingga awal Februari 2019 adalah sebanyak 16.692 kasus dengan 169 orang meninggal dunia. Menurut CNN Indonesia (2019) kasus demam berdarah ini mengalami peningkatan jumlah dari data terakhir Kemenkes tahun 2018 yang menyebutkan bahwa ada 11.293 kasus dengan 112 orang meninggal.

Tingginya jumlah kasus demam berdarah merupakan masalah yang harus diselesaikan. Pencegahan utama untuk mengatasi demam berdarah adalah pengendalian nyamuk yang merupakan vektor penyakit demam berdarah baik dalam bentuk larva maupun nyamuk dewasa (Bustamam dkk, 2018). Pemberantasan vektor demah berdarah untuk nyamuk dewasa dapat dilakukan dengan fogging atau penyemprotan lingkungan rumah dengan insektisida malathion serta diikuti dengan aplikasi abatisasi untuk mengendalikan vektor demam berdarah dalam bentuk larva (Masriadi, 2017).

Perkembangan ilmu matematika memberikan peranan dalam menganalisa permasalahan yang muncul di berbagai bidang. Misalnya peranan matematika di bidang kesehatan dalam fenomena penyebaran penyakit menular dapat dianalisis dengan pemodelan matematika. Dalam beberapa tahun terakhir, pemodelan matematika menjadi alat penting untuk memahami epidemiologi dan dinamika penyakit menular, yang mengarah pada kemajuan besar untuk pengendalian penyakit, menyediakan alat untuk menilai dampak potensial dari berbagai tindakan intervensi kesehatan masyarakat (Aguiar dan Stollenwerk, 2017).

Penelitian tentang model matematika penyebaran penyakit demam berdarah sebelumnya telah banyak dilakukan diantaranya Adi-Kusumo dkk (2014), Aini dan Shodiqin (2014), dan Bustamam dkk (2018). Penelitian Aini dan Shodiqin (2014) membahas tentang pembentukan model matematika penyebaran penyakit demam berdarah dengue, yang selanjutnya dianalisis kestabilan titik ekuilibriumnya dan dilakukan simulasi menggunakan software Matlab. Kemudian penelitian Adi-Kusumo dkk (2014) membahas tentang analisis model demam dengue dengan dua infeksi dari serotip yang berbeda dengan analisis linear. Penelitian yang dilakukan Bustamam dkk (2018) membahas tentang model matematika demam berdarah dengan berbagai intervensi seperti vaksinasi orang dewasa dan bayi baru lahir dalam populas manusia, larvasida, insektisida, dan kontrol mekanis populasi nyamuk.

Pada artikel ini dibahas mengenai analisis kestabilan model matematika penyebaran penyakit demam berdarah dengan pengaruh fogging. Artikel ini bertujuan untuk (1) mengetahui 
model matematika penyebaran penyakit demam berdarah dengan pengaruh fogging, (2) mengetahui analisis kestabilan titik ekuilibrium model matematika penyebaran penyakit demam berdarah dengan pengaruh fogging, (3) mengetahui simulasi model matematika penyebaran penyakit demam berdarah dengan pengaruh fogging.

\section{METODE}

Metode yang digunakan dalam penelitian ini adalah studi pustaka. Studi pustaka adalah metode pengumpulan data dengan mencari informasi lewat buku, jurnal, dan literatur lainnya yang bertujuan untuk membentuk suatu landasan teori. Sumber literatur yang digunakan diperoleh dari artikel, jurnal, prosiding, dan buku yang berhubungan dengan penyakit demam berdarah dan model matematika penyebaran penyakit. Selanjutnya melakukan langkah-langkah untuk mencapai tujuan penelitian. Adapun langkah-langkah yang dilakukan adalah sebagai berikut. (1) Menentukan permasalahan dunia nyata yang akan dikaji. (2) Membuat asumsiasumsi yang digunakan untuk menyusun model. (3) Membuat diagram transfer model penyebaran penyakit demam berdarah dengan pengaruh fogging yang menggambarkan penyebaran virus dengue dalam populasi manusia dan nyamuk. (4) Menyusun model matematika penyebaran penyakit demam berdarah dengan pengaruh fogging yang berupa sistem persamaan diferensial nonlinear. (5) Menentukan titik ekuilibrium bebas penyakit dan titik ekuilibrium endemik. (6) Melakukan linearisasi sistem di sekitar titik ekuilibrium bebas penyakit dan titik ekuilibrium endemik dengan menggunakan matriks Jacobian. (7) Membentuk persamaan karakteristik dari matriks Jacobian dari sistem di sekitar titik ekuilibrium bebas penyakit dan titik ekuilibrium endemik. (8) Menentukan nilai-nilai eigen yang merupakan akar persamaan karakteristik dengan memperhatikan syarat nilai eigen. (9) Menentukan bilangan reproduksi dasar berdasarkan syarat nilai eigen untuk kestabilan lokal titik ekuilibrium. (10) Menganalisis kestabilan titik ekuilibrium bebas penyakit dan titik ekuilibrium endemik. (11) Melakukan simulasi model matematika penyebaran penyakit demam berdarah dengan pengaruh fogging menggunakan software Matlab yang mana parameter-parameter diganti dengan angkaangka yang berasal dari data yang diperoleh dari berbagai sumber. (12) Penarikan kesimpulan.

\section{HASIL DAN PEMBAHASAN}

Pada bagian ini membahas tentang penyusunan model matematika penyebaran penyakit demam berdarah dengan pengaruh fogging, penentuan titik ekuilibrium bebas penyakit dan titik ekuilibrium endemik, penentuan bilangan reproduksi dasar, analisis kestabilan lokal titik ekuilibrium bebas penyakit dan titik ekuilibrium endemik, dan simulasi model dengan menggunakan software Matlab.

\subsection{Formulasi Model Matematika Penyebaran Penyakit Demam Berdarah dengan Pengaruh Fogging}

Model penyebaran penyakit demam berdarah dengan pengaruh fogging dibuat berdasarkan fakta yang ada. Dari fakta-fakta tersebut, model yang dibentuk akan menjadi sangat kompleks. Oleh karena itu, dibuat asumsi-asumsi untuk menyederhanakan model sebagai berikut. (1) Hanya terdapat populasi manusia dan populasi nyamuk dalam suatu wilayah. (2) 
Hanya terdapat satu serotipe virus dengue dalam suatu wilayah, sehingga individu yang sembuh tidak dapat terinfeksi kembali. (3) Tidak ada migrasi pada populasi manusia dan populasi nyamuk. (4) Individu yang lahir merupakan individu yang rentan terhadap penyakit. (5) Jumlah populasi manusia konstan, sehingga laju kelahiran sama dengan laju kematian. (6) Jumlah populasi nyamuk konstan. (7) Terdapat laju kematian nyamuk karena fogging. (8) Nyamuk yang terinfeksi tidak akan pernah sembuh karena umur nyamuk yang pendek. (9) Tidak ada efek resisten pada nyamuk terhadap penggunaan fogging.

Pada model ini populasi manusia dibagi menjadi tiga kelompok, yaitu kelompok individu rentan/Susceptible $\left(S_{h}\right)$ yang menyatakan kelompok individu yang belum terinfeksi oleh virus dengue dan berpotensi terinfeksi oleh virus tersebut, kelompok individu terinfeksi/Infected $\left(I_{h}\right)$ yang menyatakan kelompok individu yang terinfeksi oleh virus dengue dan berpotensi menularkan virus tersebut ke vektor penular (nyamuk), dan kelompok individu sembuh/Recovered $\left(R_{h}\right)$ yang menyatakan kelompok individu yang sembuh dari infeksi virus. Populasi nyamuk dibagi menjadi dua kelompok yaitu kelompok nyamuk rentan $\left(S_{v}\right)$ dan kelompok nyamuk terinfeksi $\left(I_{v}\right)$. Dari asumsi-asumsi diperoleh diagram transfer berikut.

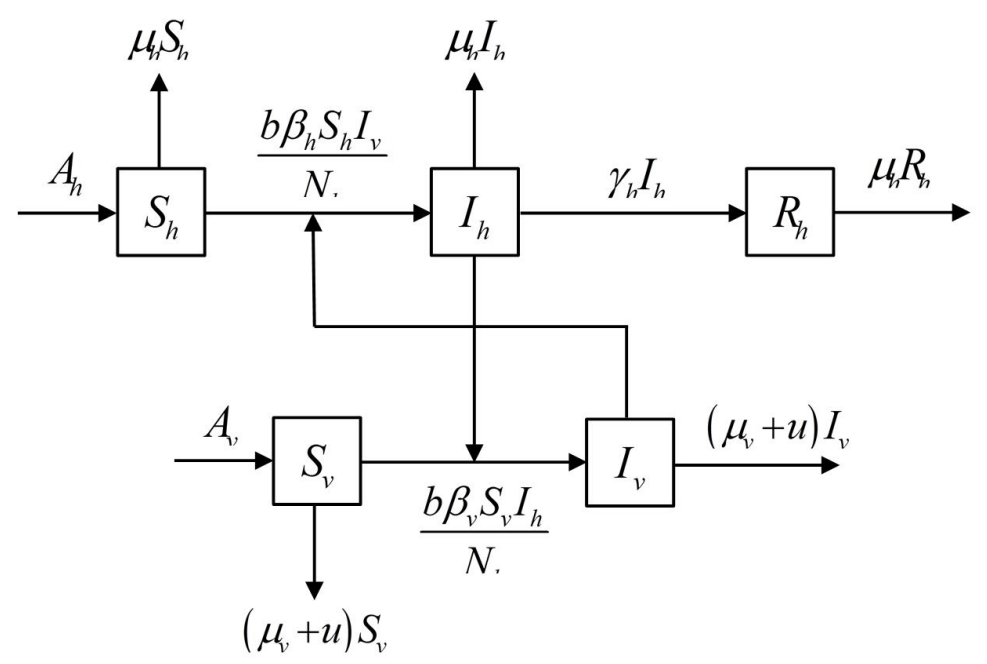

Gambar 1. Diagram Transfer Model Penyebaran Penyakit Demam Berdarah dengan Pengaruh Fogging

Dari diagram transfer pada Gambar 1, diperoleh model matematika berupa sistem persamaan diferensial sebagai berikut.

$$
\begin{gathered}
\frac{d S_{h}}{d t}=A_{h}-\frac{b \beta_{h} S_{h} I_{v}}{N_{h}}-\mu_{h} S_{h} \\
\frac{d I_{h}}{d t}=\frac{b \beta_{h} S_{h} I_{v}}{N_{h}}-\left(\mu_{h}+\gamma_{h}\right) I_{h} \\
\frac{d R_{h}}{d t}=\gamma_{h} I_{h}-\mu_{h} R_{h} \\
\frac{d S_{v}}{d t}=A_{v}-\frac{b \beta_{v} S_{v} I_{h}}{N_{h}}-\left(\mu_{v}+u\right) S_{v} \\
\frac{d I_{v}}{d t}=\frac{b \beta_{v} S_{v} I_{h}}{N_{h}}-\left(\mu_{v}+u\right) I_{v}
\end{gathered}
$$


Deskripsi parameter-parameter:

$A_{h}$ : Tingkat kelahiran manusia per kapita.

$A_{v}$ : Jumlah rekruitmen nyamuk.

$\mu_{h}$ : Laju kelahiran manusia.

$\mu_{v}$ : Laju kematian alami nyamuk.

$u$ : Laju kematian nyamuk karena fogging.

$b$ : Tingkat gigitan nyamuk pada manusia.

$\beta_{h}$ : Peluang penyebaran virus dari nyamuk yang terinfeksi ke individu rentan.

$\beta_{v}$ : Peluang penyebaran virus dari individu yang terinfeksi ke nyamuk rentan.

$\gamma_{h}$ : Laju pemulihan individu yang terinfeksi.

$N_{h}$ : Jumlah populasi manusia

\subsection{Titik Ekuilibrium}

Titik ekuilibrium diperoleh dengan menjadikan $\frac{d S_{h}}{d t}=0, \frac{d I_{h}}{d t}=0, \frac{d R_{h}}{d t}=0, \frac{d S_{v}}{d t}=0$, dan $\frac{d I_{v}}{d t}=0$ dari sistem persamaan (1) sehingga diperoleh dua titik ekuilibrium yaitu titik ekuilibrium bebas penyakit dan titik ekuilibrium endemik.

\section{Titik Ekuilibrium Bebas Penyakit}

Titik ekuilibrium bebas penyakit adalah suatu keadaan tidak terjadi penyebaran penyakit menular (demam berdarah) dalam suatu populasi. Titik ekuilibrium bebas penyakit diberikan oleh $E_{0}=\left(S_{h}, I_{h}, \mathrm{R}_{h}, S_{v}, I_{v}\right)=\left(\frac{A_{h}}{\mu_{h}}, 0,0, \frac{A_{v}}{\mu_{v}+u}, 0\right)$.

\section{Titik Ekuilibrium Endemik}

Titik ekuilibrium endemik adalah suatu keadaan dimana terjadi infeksi penyakit di dalam populasi sehingga $I_{h} \neq 0$ dan $I_{v} \neq 0$. Titik ekuilibrium endemik diberikan oleh $E_{1}=\left(S_{h}^{*}, I_{h}^{*}, R_{h}^{*}, S_{v}^{*}, I_{v}^{*}\right)$ dengan

$$
\begin{aligned}
S_{h}^{*}= & \frac{N_{h}\left(\mu_{v}+u\right)\left(b \beta_{v} A_{h}+\mu_{h} \mu_{v} N_{h}+u \mu_{h} N_{h}+\mu_{v} \gamma_{h} N_{h}+u \gamma_{h} N_{h}\right)}{b \beta_{v}\left(b \beta_{h} A_{v}+\mu_{h} \mu_{v} N_{h}+u \mu_{h} N_{h}\right)} \\
I_{h}^{*}= & \frac{b^{2} \beta_{h} \beta_{v} A_{h} A_{v}-\mu_{h}^{2} \mu_{v}^{2} N_{h}^{2}-\mu_{h}^{2} \mu_{v}^{2} \gamma_{h} N_{h}^{2}-2 u \mu_{h}^{2} \mu_{v} N_{h}^{2}-2 u \mu_{h} \mu_{v} \gamma_{h} N_{h}^{2}}{b \beta_{v}\left(b \beta_{h} \mu_{h} A_{v}+b \beta_{h} \gamma_{h} A_{v}+\mu_{h}^{2} \mu_{v} N_{h}+\mu_{h} \mu_{v} \gamma_{h} N_{h}+u \mu_{h}^{2} N_{h}+u \mu_{h} \gamma_{h} N_{h}\right)} \\
R_{h}^{*}= & \frac{\gamma_{h}\left(b^{2} \beta_{h} \beta_{v} A_{h} A_{v}-\mu_{h}^{2} \mu_{v}^{2} N_{h}^{2}-\mu_{h} \mu_{v}^{2} \gamma_{h} N_{h}^{2}-2 u \mu_{h}^{2} \mu_{v} N_{h}^{2}-2 u \mu_{h} \mu_{h} \gamma_{h} \gamma_{h} N_{h}^{2}\right.}{b \beta_{v} \mu_{h}\left(b \beta_{h} \mu_{h} A_{v}+b \beta_{h} \gamma_{h} A_{v}+\mu_{h}^{2} \mu_{v} N_{h}+\mu_{h} \mu_{v} \gamma_{h} N_{h}+u \mu_{h}^{2} N_{h}+u \mu_{h} \gamma_{h} N_{h}\right)}
\end{aligned}
$$




$$
\begin{aligned}
S_{v}^{*}= & \frac{N_{h}\left(b \beta_{h} \mu_{h} A_{v}+b \beta_{h} \gamma_{h} A_{v}+\mu_{h}^{2} \mu_{v} N_{h}+\mu_{h} \mu_{v} \gamma_{h} N_{h}+u \mu_{h}^{2} N_{h}+u \mu_{h} \gamma_{h} N_{h}\right)}{b \beta_{h}\left(b \beta_{v} A_{h}+\mu_{h} \mu_{v} N_{h}+u \mu_{h} N_{h}+\mu_{v} \gamma_{h} N_{h}+u \gamma_{h} N_{h}\right)} \\
I_{v}^{*}= & \frac{-u^{2} \mu_{h}^{2} N_{h}^{2}-u^{2} \mu_{h} \gamma_{h} N_{h}^{2}}{b \beta_{h}\left(\mu_{v}+u\right)\left(b \beta_{v} A_{h}+\mu_{h} \mu_{v} N_{h}+u \mu_{h} N_{h}+\mu_{v} \gamma_{h} N_{h}+u \gamma_{h} N_{h}\right)}
\end{aligned}
$$

\subsection{Bilangan Reproduksi Dasar}

Bilangan reproduksi dasar $\left(R_{0}\right)$ adalah banyaknya individu rentan yang terinfeksi oleh individu lain yang terinfeksi. Jika $R_{0}<1$, maka penyakit akan menghilang dari populasi. Jika $R_{0}>1$, maka penyakit akan meningkat menjadi wabah. Bilangan reproduksi dasar diperoleh dengan perhitungan nilai eigen dari matriks Jacobian yang dihitung pada titik ekuilibrium bebas penyakit. Berikut matriks Jacobian dari sistem persamaan (1) di sekitar titik ekuilibrium bebas penyakit.

$$
J\left(f\left(E_{0}\right)\right)=\left[\begin{array}{ccccc}
-\mu_{h} & 0 & 0 & 0 & -\frac{b \beta_{h} A_{h}}{\mu_{h} N_{h}} \\
0 & -\left(\mu_{h}+\gamma_{h}\right) & 0 & 0 & \frac{b \beta_{h} A_{h}}{\mu_{h} N_{h}} \\
0 & \gamma_{h} & -\mu_{h} & 0 & 0 \\
0 & -\frac{b \beta_{v} A_{v}}{N_{h}\left(\mu_{v}+u\right)} & 0 & -\left(\mu_{v}+u\right) & 0 \\
0 & \frac{b \beta_{v} A_{v}}{N_{h}\left(\mu_{v}+u\right)} & 0 & 0 & -\left(\mu_{v}+u\right)
\end{array}\right]
$$

Selanjutnya melakukan linearisasi. Dari matriks (2) dibentuk persamaan karakteristik $\left|\lambda I-J\left(f\left(E_{0}\right)\right)\right|=0$ sehingga diperoleh nilai eigen $\lambda_{1}=-\mu_{h}, \lambda_{2}=-\mu_{h}, \lambda_{3}=-\mu_{v}-u$ dan

$$
\lambda_{45}=\frac{-\left(\mu_{v}+u+\mu_{h}+\gamma_{h}\right) \pm \sqrt{\left(\mu_{v}+u+\mu_{h}+\gamma_{h}\right)^{2}-4\left(\mu_{h} \mu_{v}+u \mu_{h}+\mu_{v} \gamma_{h}+u \gamma_{h}-\frac{b^{2} \beta_{h} \beta_{v} A_{h} A_{v}}{\mu_{h}\left(\mu_{v}+u\right) N_{h}^{2}}\right)}}{2} .
$$

Suatu titik kesetimbangan dikatakan stabil asimtotik lokal jika semua bagian real nilai eigen bernilai negatif. Agar $\lambda_{4}$ merupakan bagian real negatif, maka

$$
\begin{aligned}
& \frac{-\left(\mu_{v}+u+\mu_{h}+\gamma_{h}\right)+\sqrt{\left(\mu_{v}+u+\mu_{h}+\gamma_{h}\right)^{2}-4\left(\mu_{h} \mu_{v}+u \mu_{h}+\mu_{v} \gamma_{h}+u \gamma_{h}-\frac{b^{2} \beta_{h} \beta_{v} A_{h} A_{v}}{\mu_{h}\left(\mu_{v}+u\right) N_{h}^{2}}\right)}}{2}<0 \\
\Leftrightarrow & \sqrt{\left(\mu_{v}+u+\mu_{h}+\gamma_{h}\right)^{2}-4\left(\mu_{h} \mu_{v}+u \mu_{h}+\mu_{v} \gamma_{h}+u \gamma_{h}-\frac{b^{2} \beta_{h} \beta_{v} A_{h} A_{v}}{\mu_{h}\left(\mu_{v}+u\right) N_{h}^{2}}\right)}<\left(\mu_{v}+u+\mu_{h}+\gamma_{h}\right) \\
\Leftrightarrow & \left(\mu_{v}+u+\mu_{h}+\gamma_{h}\right)^{2}-4\left(\mu_{h} \mu_{v}+u \mu_{h}+\mu_{v} \gamma_{h}+u \gamma_{h}-\frac{b^{2} \beta_{h} \beta_{v} A_{h} A_{v}}{\mu_{h}\left(\mu_{v}+u\right) N_{h}^{2}}\right)<\left(\mu_{v}+u+\mu_{h}+\gamma_{h}\right)^{2}
\end{aligned}
$$




$$
\begin{aligned}
& \Leftrightarrow-\left(\mu_{h} \mu_{v}+u \mu_{h}+\mu_{v} \gamma_{h}+u \gamma_{h}-\frac{b^{2} \beta_{h} \beta_{v} A_{h} A_{v}}{\mu_{h}\left(\mu_{v}+u\right) N_{h}^{2}}\right)<0 \\
& \Leftrightarrow-\left(\left(\mu_{h}+\gamma_{h}\right)\left(\mu_{v}+u\right)\right)+\frac{b^{2} \beta_{h} \beta_{v} A_{h} A_{v}}{\mu_{h}\left(\mu_{v}+u\right) N_{h}^{2}}<0 \\
& \Leftrightarrow-1+\frac{b^{2} \beta_{h} \beta_{v} A_{h} A_{v}}{\mu_{h} N_{h}^{2}\left(\mu_{v}+u\right)\left(\mu_{h}+\gamma_{h}\right)\left(\mu_{v}+u\right)}<0 \\
& \Leftrightarrow \frac{b^{2} \beta_{h} \beta_{v} A_{h} A_{v}}{\mu_{h} N_{h}^{2}\left(\mu_{v}+u\right)\left(\mu_{h}+\gamma_{h}\right)\left(\mu_{v}+u\right)}<1
\end{aligned}
$$

Berdasarkan asumsi nilai eigen yang merupakan bagian real negatif, maka titik ekuilibrium bebas penyakit. Hal ini berarti banyaknya individu rentan yang terinfeksi yang disebabkan oleh individu terinfeksi adalah nol atau kurang dari satu. Sehingga

$$
R_{0}=\frac{b^{2} \beta_{h} \beta_{v} A_{h} A_{v}}{\mu_{h} N_{h}^{2}\left(\mu_{v}+u\right)\left(\mu_{h}+\gamma_{h}\right)\left(\mu_{v}+u\right)} .
$$

\subsection{Analisis Kestabilan Lokal Titik Ekuilibrium Bebas Penyakit}

Berdasarkan nilai eigen yang diperoleh yaitu $\lambda_{1}=-\mu_{h}, \lambda_{2}=-\mu_{h}, \lambda_{3}=-\mu_{v}-u$, dan

$$
\lambda_{45}=\frac{-\left(\mu_{v}+u+\mu_{h}+\gamma_{h}\right) \pm \sqrt{\left(\mu_{v}+u+\mu_{h}+\gamma_{h}\right)^{2}-4\left(\mu_{h} \mu_{v}+u \mu_{h}+\mu_{v} \gamma_{h}+u \gamma_{h}-\frac{b^{2} \beta_{h} \beta_{v} A_{h} A_{v}}{\mu_{h}\left(\mu_{v}+u\right) N_{h}^{2}}\right)}}{2} .
$$

Untuk selanjutnya $\lambda_{45}$ akan dinyatakan dalam $R_{0}$ sebagai berikut.

$$
\lambda_{45}=-\frac{1}{2}\left(\mu_{v}+u+\mu_{h}+\gamma_{h}\right) \pm \sqrt{\left(\mu_{v}+u+\mu_{h}+\gamma_{h}\right)^{2}-4\left(\mu_{h}+\gamma_{h}\right)\left(\mu_{v}+u\right)\left(1-R_{0}\right)} .
$$

Agar $\lambda_{4}$ dan $\lambda_{5}$ merupakan bagian real tak nol maka

$$
\left(\mu_{v}+u+\mu_{h}+\gamma_{h}\right)^{2}-4\left(\mu_{h}+\gamma_{h}\right)\left(\mu_{v}+u\right)\left(1-R_{0}\right)>0 .
$$

Jika $R_{0}<1$, maka $\left(1-R_{0}\right)>0$. Sehingga $4\left(\mu_{h}+\gamma_{h}\right)\left(\mu_{v}+u\right)\left(1-R_{0}\right)>0$. Akibatnya

$$
\sqrt{\left(\mu_{v}+u+\mu_{h}+\gamma_{h}\right)^{2}-4\left(\mu_{h}+\gamma_{h}\right)\left(\mu_{v}+u\right)\left(1-R_{0}\right)}<\sqrt{\left(\mu_{v}+u+\mu_{h}+\gamma_{h}\right)^{2}}=\left(\mu_{v}+u+\mu_{h}+\gamma_{h}\right)
$$

Sehingga $\lambda_{4}<0$ dan $\lambda_{5}<0$. Dilihat dari nilai eigen pada titik ekuilibrium bebas penyakit mempunyai akar-akar bagian realnya bernilai negatif jika bilangan reproduksinya kurang dari satu. Sehingga dapat disimpulkan titik ekuilibrium bebas penyakit stabil asimtotik lokal.

\subsection{Analisis Kestabilan Lokal Titik Ekuilibrium Endemik}

Berikut matriks Jacobian dari sistem persamaan (1) di sekitar titik ekuilibrium endemik $\left(E_{1}\right)$. 


$$
J\left(f\left(E_{1}\right)\right)=\left[\begin{array}{ccccc}
-\frac{b \beta_{h} I_{v}^{*}}{N_{h}}-\mu_{h} & 0 & 0 & 0 & -\frac{b \beta_{h} S_{h}^{*}}{N_{h}} \\
\frac{b \beta_{h} I_{v}^{*}}{N_{h}} & -\left(\mu_{h}+\gamma_{h}\right) & 0 & 0 & \frac{b \beta_{h} S_{h}^{*}}{N_{h}} \\
0 & \gamma_{h} & -\mu_{h} & 0 & 0 \\
0 & -\frac{b \beta_{v} S_{v}^{*}}{N_{h}} & 0 & -\frac{b \beta_{v} I_{h}^{*}}{N_{h}}-\left(\mu_{v}+u\right) & 0 \\
0 & \frac{b \beta_{v} S_{v}^{*}}{N_{h}} & 0 & \frac{b \beta_{v} I_{h}^{*}}{N_{h}} & -\left(\mu_{v}+u\right)
\end{array}\right]
$$

Dari matriks (4) dibentuk persamaan karakteristik $\left|\lambda I-J\left(f\left(E_{1}\right)\right)\right|=0$ sehingga diperoleh persamaan

$$
\lambda^{5}+A \lambda^{4}+B \lambda^{3}+C \lambda^{2}+D \lambda+E=0
$$

dengan

$$
\begin{aligned}
& A=\frac{b \beta_{h} I_{v}^{*}}{N_{h}}+3 \mu_{h}+\gamma_{h}+\frac{b \beta_{v} I_{h}^{*}}{N_{h}}+2 \mu_{v}+2 u \\
& B=2 \frac{b \beta_{h} \mu_{h} I_{v}^{*}}{N_{h}}+\frac{b \beta_{h} \gamma_{h} I_{v}^{*}}{N_{h}}+3 \mu_{h}^{2}+2 \mu_{h} \gamma_{h}+\frac{b^{2} \beta_{h} \beta_{v} I_{h}^{*} I_{v}^{*}}{N_{h}^{2}}+2 \frac{b \beta_{h} \mu_{v} I_{v}^{*}}{N_{h}}+2 \frac{b u \beta_{h} I_{v}^{*}}{N_{h}}+3 \frac{b \beta_{v} \mu_{h} I_{h}^{*}}{N_{h}} \\
& +6 \mu_{h} \mu_{v}+6 u \mu_{h}+\frac{b \beta_{v} \gamma_{h} I_{h}^{*}}{N_{h}}+2 \mu_{v} \gamma_{h}+2 u \gamma_{h}+\frac{b \beta_{v} \mu_{v} I_{h}^{*}}{N_{h}}+\frac{b u \beta_{v} I_{h}^{*}}{N_{h}}+\mu_{v}^{2}+2 u \mu_{v}+u^{2}- \\
& \frac{b^{2} \beta_{h} \beta_{v} S_{h}^{*} S_{v}^{*}}{N_{h}^{2}} \\
& C=2 \frac{b^{2} \beta_{h} \beta_{v} \mu_{h} I_{h}^{*} I_{v}^{*}}{N_{h}^{2}}+4 \frac{b \beta_{h} \mu_{h} \mu_{v} I_{v}^{*}}{N_{h}}+4 \frac{b u \beta_{h} \mu_{h} I_{v}^{*}}{N_{h}}+\frac{b^{2} \beta_{h} \beta_{v} \gamma_{h} I_{h}^{*} I_{v}^{*}}{N_{h}^{2}}+2 \frac{b \beta_{h} \mu_{v} \gamma_{h} I_{v}^{*}}{N_{h}}+2 \frac{b u \beta_{h} \gamma_{h} I_{v}^{*}}{N_{h}} \\
& +3 \frac{b \beta_{v} \mu_{h}^{2} I_{h}^{*}}{N_{h}}+6 \mu_{h}^{2} \mu_{v}+6 u \mu_{h}^{2}+2 \frac{b \beta_{v} \mu_{h} \gamma_{h} I_{h}^{*}}{N_{h}}+4 \mu_{h} \mu_{v} \gamma_{h}+4 u \mu_{h} \gamma_{h}+\frac{b^{2} \beta_{h} \beta_{v} \mu_{v} I_{h}^{*} I_{v}^{*}}{N_{h}^{2}}+ \\
& \frac{b \beta_{h} \mu_{v}^{2} I_{v}^{*}}{N_{h}}+2 \frac{b u \beta_{h} \mu_{v} I_{v}^{*}}{N_{h}}+2 \frac{b \beta_{v} \mu_{h} \mu_{v} I_{h}^{*}}{N_{h}}+3 \mu_{h} \mu_{v}^{2}+6 u \mu_{h} \mu_{v}+\frac{b^{2} u \beta_{h} \beta_{v} I_{h}^{*} I_{v}^{*}}{N_{h}^{2}}+\frac{b u^{2} \beta_{h} I_{v}^{*}}{N_{h}}+ \\
& 2 \frac{b u \beta_{v} \mu_{h} I_{h}^{*}}{N_{h}}+3 u^{2} \mu_{h}-2 \frac{b^{2} \beta_{h} \beta_{v} \mu_{h} S_{h}^{*} S_{v}^{*}}{N_{h}^{2}}+\frac{b \beta_{v} \mu_{v} \gamma_{h} I_{h}^{*}}{N_{h}}+\mu_{v}^{2} \gamma_{h}+2 u \mu_{v} \gamma_{h}+\frac{b u \beta_{v} \gamma_{h} I_{h}^{*}}{N_{h}}+u^{2} \gamma_{h} \\
& +\frac{b \beta_{h} \mu_{h}^{2} I_{v}^{*}}{N_{h}}+\frac{b \beta_{h} \mu_{h} \gamma_{h} I_{v}^{*}}{N_{h}}+\mu_{h}^{3}+\mu_{h}^{2} \gamma_{h}+\frac{b \beta_{v} \mu_{h} \mu_{v} I_{h}^{*}}{N_{h}}+\frac{b u \beta_{v} \mu_{h} I_{h}^{*}}{N_{h}}-\frac{b^{2} \beta_{h} \beta_{v} \mu_{v} S_{h}^{*} S_{v}^{*}}{N_{h}^{2}}- \\
& \frac{b^{2} u \beta_{h} \beta_{v} S_{h}^{*} S_{v}^{*}}{N_{h}^{2}} \\
& D=2 \frac{b^{2} \beta_{h} \beta_{v} \mu_{h} \mu_{v} I_{h}^{*} I_{v}^{*}}{N_{h}^{2}}+2 \frac{b^{2} u \beta_{h} \beta_{v} \mu_{h} I_{h}^{*} I_{v}^{*}}{N_{h}^{2}}+2 \frac{b \beta_{h} \mu_{h} \mu_{v}^{2} I_{v}^{*}}{N_{h}}+4 \frac{b u \beta_{h} \mu_{h} \mu_{v} I_{v}^{*}}{N_{h}}+2 \frac{b u^{2} \beta_{h} \mu_{h} I_{v}^{*}}{N_{h}}+ \\
& \frac{b^{2} \beta_{h} \beta_{v} \mu_{v} \gamma_{h} I_{h}^{*} I_{v}^{*}}{N_{h}^{2}}+\frac{b^{2} u \beta_{h} \beta_{v} \gamma_{h} I_{h}^{*} I_{v}^{*}}{N_{h}^{2}}+\frac{b \beta_{h} \mu_{v}^{2} \gamma_{h} I_{v}^{*}}{N_{h}}+2 \frac{b u \beta_{h} \mu_{v} \gamma_{h} I_{v}^{*}}{N_{h}}+\frac{b u^{2} \beta_{h} \gamma_{h} I_{v}^{*}}{N_{h}}+3 \frac{b \beta_{v} \mu_{h}^{2} \mu_{v} I_{h}^{*}}{N_{h}}+
\end{aligned}
$$




$$
\begin{aligned}
& 3 \frac{b u \beta_{v} \mu_{h}^{2} I_{h}^{*}}{N_{h}}+3 \mu_{h}^{2} \mu_{v}^{2}+6 u \mu_{h}^{2} \mu_{v}+3 u^{2} \mu_{h}^{2}+2 \frac{b \beta_{v} \mu_{h} \mu_{v} \gamma_{h} I_{h}^{*}}{N_{h}}+2 \frac{b u \beta_{v} \mu_{h} \gamma_{h} I_{h}^{*}}{N_{h}}+3 \mu_{h} \mu_{v}^{2} \gamma_{h} \\
& +4 u \mu_{h} \mu_{v} \gamma_{h}+2 u^{2} \mu_{h} \gamma_{h}-2 \frac{b^{2} \beta_{h} \beta_{v} \mu_{h} \mu_{v} S_{h}^{*} S_{v}^{*}}{N_{h}^{2}}-2 \frac{b^{2} u \beta_{h} \beta_{v} \mu_{h} S_{h}^{*} S_{v}^{*}}{N_{h}^{2}}+\frac{b^{2} \beta_{h} \beta_{v} \mu_{h}^{2} I_{h}^{*} I_{v}^{*}}{N_{h}^{2}}+ \\
& 2 \frac{b \beta_{h} \mu_{h}^{2} \mu_{v} I_{v}^{*}}{N_{h}}+2 \frac{b u \beta_{h} \mu_{h}^{2} I_{v}^{*}}{N_{h}}+\frac{b^{2} \beta_{h} \beta_{v} \mu_{h} \gamma_{h} I_{h}^{*} I_{v}^{*}}{N_{h}^{2}}+2 \frac{b \beta_{h} \mu_{h} \mu_{v} \gamma_{h} I_{v}^{*}}{N_{h}}+2 \frac{b u \beta_{h} \mu_{h} \gamma_{h} I_{v}^{*}}{N_{h}}+ \\
& \frac{b \beta_{v} \mu_{h}^{3} I_{h}^{*}}{N_{h}}+2 \mu_{h}^{3} \mu_{v}+2 u \mu_{h}^{3}+\frac{b \beta_{v} \mu_{h}^{2} \gamma_{h} I_{h}^{*}}{N_{h}}+\mu_{h}^{2} \mu_{v} \gamma_{h}+2 u \mu_{h}^{2} \gamma_{h}-\frac{b^{2} \beta_{h} \beta_{v} \mu_{h}^{2} S_{h}^{*} S_{v}^{*}}{N_{h}^{2}} \\
E= & \frac{b^{2} \beta_{h} \beta_{v} \mu_{h}^{2} \mu_{v} I_{h}^{*} I_{v}^{*}}{N_{h}^{2}}+\frac{b^{2} u \beta_{h} \beta_{v} \mu_{h}^{2} I_{h}^{*} I_{v}^{*}}{N_{h}^{2}}+\frac{b \beta_{h} \mu_{h}^{2} \mu_{v}^{2} I_{v}^{*}}{N_{h}}+2 \frac{b u \beta_{h} \mu_{h}^{2} \mu_{v} I_{v}^{*}}{N_{h}}+\frac{b u^{2} \beta_{h} \mu_{h}^{2} I_{v}^{*}}{N_{h}}+ \\
& \frac{b^{2} \beta_{h} \beta_{v} \mu_{h} \mu_{v} \gamma_{h} I_{h}^{*} I_{v}^{*}}{N_{h}^{2}}+\frac{b^{2} u \beta_{h} \beta_{v} \mu_{h} \gamma_{h} I_{h}^{*} I_{v}^{*}}{N_{h}^{2}}+\frac{b \beta_{h} \mu_{h} \mu_{v}^{2} \gamma_{h} I_{v}^{*}}{N_{h}}+2 \frac{b u \beta_{h} \mu_{h} \mu_{v} \gamma_{h} I_{v}^{*}}{N_{h}}+ \\
& \frac{b u^{2} \beta_{h} \mu_{h} \gamma_{h} I_{v}^{*}}{N_{h}}+\frac{b \beta_{v} \mu_{h}^{3} \mu_{v} I_{h}^{*}}{N_{h}}+\frac{b u \beta_{v} \mu_{h}^{3} I_{h}^{*}}{N_{h}}+\mu_{h}^{3} \mu_{v}^{2}+2 u \mu_{h}^{3} \mu_{v}+u^{2} \mu_{h}^{3}+\frac{b \beta_{v} \mu_{h}^{2} \mu_{v} \gamma_{h} I_{h}^{*}}{N_{h}} \\
& +\frac{b u \beta_{v} \mu_{h}^{2} \gamma_{h} I_{h}^{*}}{N_{h}}+\mu_{h}^{2} \mu_{v}^{2} \gamma_{h}+2 u \mu_{h}^{2} \mu_{v} \gamma_{h}+u^{2} \mu_{h}^{2} \gamma_{h}-\frac{b^{2} \beta_{h} \beta_{v} \mu_{h}^{2} \mu_{v} S_{h}^{*} S_{v}^{*}}{N_{h}^{2}}-\frac{b^{2} u \beta_{h} \beta_{v} \mu_{h}^{2} S_{h}^{*} S_{v}^{*}}{N_{h}^{2}}
\end{aligned}
$$

Persamaan (5) mempunyai bagian real negatif jika $A>0, B>0, C>0, D>0$, dan $E>0$. Koefisien A, B, C, D, dan E bernilai positif bergantung pada nilai $R_{0}$. Saat kondisi $R_{0}<1$, maka $A<0$. Jika $R_{0}=1$ dan $R_{0}>1$ maka $A>0$. Untuk koefisien $\mathrm{B}, \mathrm{C}, \mathrm{D}$, dan E bernilai positif saat kondisi $R_{0}>1$.

Kestabilan di sekitar titik ekuilibrium endemik dianalisis menggunakan kriteria RouthHurwitz dan bilangan reproduksi dasar $\left(R_{0}\right)$. Hal ini disebabkan karena persamaan yang diperoleh sulit untuk dilakukan perhitungan nilai eigen secara langsung. Berdasarkan koefisien dari persamaan (5) dapat dibentuk matriks Routh-Hurwitz berikut.

$$
H=\left[\begin{array}{lllll}
A & C & E & 0 & 0 \\
1 & B & D & 0 & 0 \\
0 & A & C & E & 0 \\
0 & 1 & B & D & 0 \\
0 & 0 & A & C & E
\end{array}\right]
$$

Sehingga diperoleh determinan Routh-Hurwitz yaitu $D_{1}=A, D_{2}=A B-C$, $D_{3}=A B C+A E-A^{2} D-C^{2}, D_{4}=B C D+2 A D E+B C E-A B^{2} E-A^{2} D^{2}-C^{2} D-E^{2}, \quad$ dan $D_{5}=A B C D E+2 A D E^{2}+B C E^{2}-A B^{2} E^{2}-A^{2} D^{2} E-C^{2} D E-E^{3}$. Akar-akar dari persamaan (4.25) mempunyai bagian real negatif jika $D_{1}>0, D_{2}>0, D_{3}>0, D_{4}>0$, dan $D_{5}>0$. Berdasarkan kondisi $R_{0}>1$ maka $A>0, B>0, C>0, D>0$, dan $E>0$ sehingga diperoleh $D_{1}>0, D_{2}>0, D_{3}>0, D_{4}>0$, dan $D_{5}>0$. Dengan demikian dapat disimpulkan bahwa jika $R_{0}>1$ kriteria Routh-Hurwitz terpenuhi, maka titik ekuilibrium $E_{1}$ akan stabil jika $R_{0}>1$. Sehingga dapat disimpulkan titik ekuilibrium bebas penyakit stabil asimtotik lokal. 


\subsection{Simulasi Model Matematika Penyebaran Demam Berdarah dengan Pengaruh Fogging saat Bebas Penyakit}

Pada simulasi ini, jumlah awal manusia sehat adalah 1000 sehingga nilai awal pada manusia rentan adalah $S_{h}(0)=999,97$, nilai awal pada manusia terinfeksi adalah $I_{h}(0)=0,053$, nilai awal manusia sembuh adalah $R_{h}(0)=0,063$. Jumlah nilai awal nyamuk rentan adalah 262,26 sehingga nilai awal nyamuk rentan adalah $S_{v}(0)=262,267$, dan nilai awal nyamuk terinfeksi adalah $I_{v}(0)=0,0016$. Laju rekruitmen nyamuk $\left(A_{v}\right)$ diasumsikan sebesar 271. Berdasarkan nilai-nilai parameter pada Tabel 1 dan nilai parameter laju rekruitmen nyamuk, diperoleh $R_{0}=\frac{b^{2} \beta_{h} \beta_{v} A_{h} A_{v}}{\mu_{h} N_{h}^{2}\left(\mu_{v}+u\right)\left(\mu_{h}+\gamma_{h}\right)\left(\mu_{v}+u\right)}=0,998741<1$.

Tabel 1. Nilai-nilai Parameter Model Penyebaran Penyakit Demam Berdarah dengan Pengaruh Fogging

\begin{tabular}{|c|c|c|c|}
\hline Keterangan & Simbol & Nilai & Sumber \\
\hline Tingkat kelahiran manusia per kapita. & $A_{h}$ & $\frac{1000}{65 \times 365}$ & $\begin{array}{l}\text { Bustamam } \\
\text { dkk (2018 }\end{array}$ \\
\hline Jumlah rekruitmen nyamuk. & $A_{v}$ & 300 & Asumsi \\
\hline Laju kelahiran manusia. & $\mu_{h}$ & $\frac{1}{65 \times 365}$ & $\begin{array}{l}\text { Bustamam } \\
\text { dkk }(2018\end{array}$ \\
\hline Laju kematian alami nyamuk. & $\mu_{v}$ & $\frac{1}{30}$ & $\begin{array}{l}\text { Bustamam } \\
\text { dkk (2018 }\end{array}$ \\
\hline Laju kematian nyamuk karena fogging. & $u$ & 1 & $\begin{array}{l}\text { Bustamam } \\
\text { dkk (2018 }\end{array}$ \\
\hline Tingkat gigitan nyamuk pada manusia. & $b$ & 1 & $\begin{array}{l}\text { Bustamam } \\
\text { dkk (2018 }\end{array}$ \\
\hline $\begin{array}{l}\text { Peluang penyebaran virus dari nyamuk yang } \\
\text { terinfeksi ke individu rentan. }\end{array}$ & $\beta_{h}$ & 0.75 & $\begin{array}{l}\text { Side dkk } \\
(2018)\end{array}$ \\
\hline $\begin{array}{l}\text { Peluang penyebaran virus dari individu yang } \\
\text { terinfeksi ke nyamuk rentan. }\end{array}$ & $\beta_{v}$ & 0.375 & $\begin{array}{l}\text { Side dkk } \\
(2018)\end{array}$ \\
\hline Laju pemulihan individu yang terinfeksi. & $\gamma_{h}$ & $\frac{1}{14}$ & $\begin{array}{l}\text { Bustamam } \\
\text { dkk }(2018\end{array}$ \\
\hline Jumlah populasi manusia & $N_{h}$ & 1000 & $\begin{array}{l}\text { Bustamam } \\
\text { dkk (2018 }\end{array}$ \\
\hline
\end{tabular}

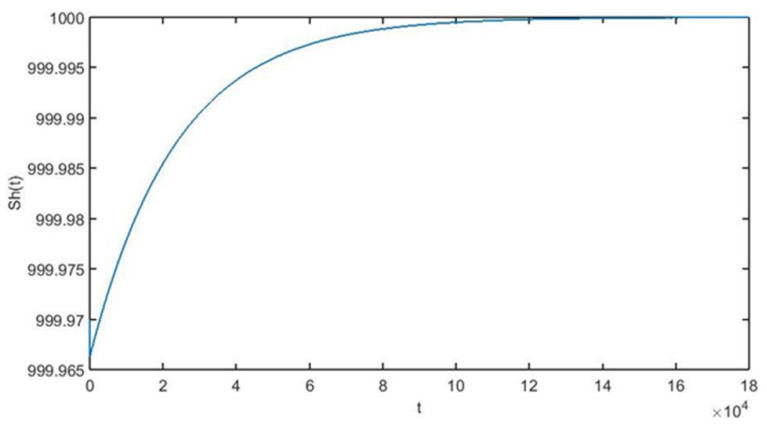

Gambar 2. Grafik Dinamika Populasi Manusia Rentan $\left(S_{h}\right)$ dengan Pengaruh Fogging terhadap Waktu (t) Saat Bebas Penyakit 
Pada Gambar 2 terlihat bahwa jumlah populasi manusia rentan yang awalnya bernilai 999,97 mengalami penurunan di titik di bawah 999,97 dan di atas 999,965 untuk waktu yang singkat kemudian mengalami kenaikan seiring dengan bertambahnya waktu hingga mencapai titik kesetimbangan. Grafik tersebut menjelaskan bahwa pada waktu tak terhingga diperoleh nilai populasi manusia rentan terhadap waktu pada simulasi ini diperkirakan jumlah populasi manusia rentan dalam jangka waktu yang panjang akan berjumlah 1000 pada hari ke 120.000 lebih. Jadi pada keadaan tersebut, sistem berada pada kondisi stabil.

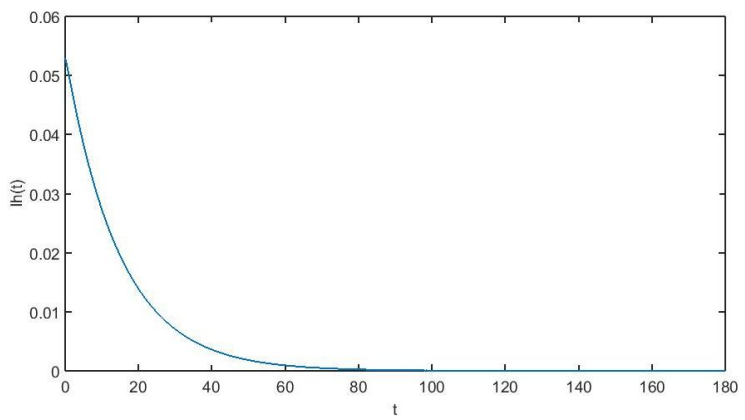

Gambar 3. Grafik Dinamika Populasi Manusia Terinfeksi $\left(I_{h}\right)$ dengan Pengaruh Fogging terhadap Waktu (t) saat Bebas Penyakit

Gambar 3 menunjukkan bahwa jumlah manusia terinfeksi dengan nilai awal 0,053 mengalami penurunan seiring dengan bertambahnya waktu hingga mencapai titik kesetimbangan. Grafik tersebut menjelaskan bahwa pada waktu tak terhingga diperoleh jumlah manusia terinfeksi terhadap waktu menuju ke titik nol pada hari ke 60 lebih dan tidak mengalami perubahan. Dengan kata lain jumlah populasi manusia yang terinfeksi dalam waktu yang panjang penyakit Demam Berdarah akan menghilang.

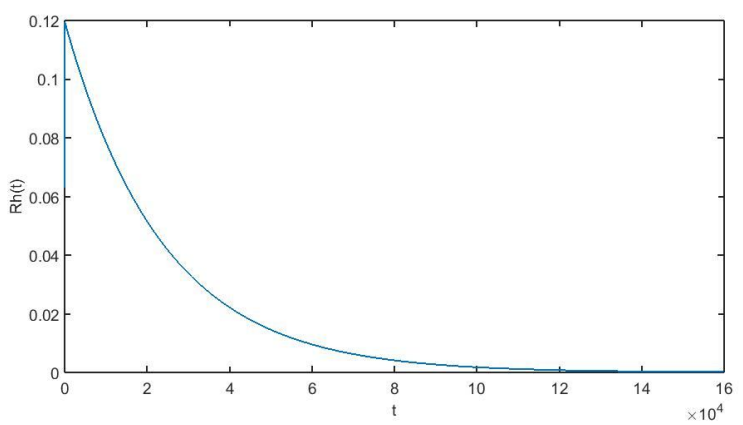

Gambar 4. Grafik Dinamika Populasi Manusia Sembuh $\left(R_{h}\right)$ dengan Pengaruh Fogging terhadap Waktu (t) saat Bebas Penyakit

Pada Gambar 4 terlihat bahwa jumlah manusia sembuh dengan nilai awal 0,063 bertambah mencapai titik 0,12 untuk waktu yang singkat. Kemudian mengalami penurunan seiring bertambahnya waktu hingga mencapai titik kestimbangan. Grafik tersebut menjelaskan bahwa pada waktu tak hingga diperoleh nilai populasi manusia sembuh terhadap waktu yaitu menuju titik nol pada hari ke 120.000 lebih. Pada kondisi tersebut sistem berada dalm kondisi stabil. 
12 | Siti Windawati, Ali Shodiqin, Aurora Nur Aini - Analisis Kestabilan Model Matematika Penyebaran Penyakit Demam Berdarah ....

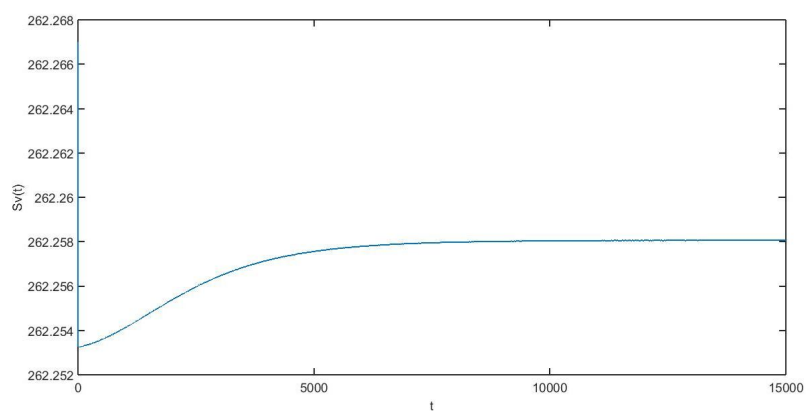

Gambar 5. Grafik Dinamika Populasi Nyamuk Rentan $\left(S_{v}\right)$ dengan Pengaruh Fogging terhadap Waktu (t) saat Bebas Penyakit

Gambar 5 menunjukkan bahwa jumlah nyamuk rentan dengan nilai awal 262,267 berkurang mencapai titik di bawah 262,254 dan di atas 262,252 untuk waktu yang singkat. Kemudian mengalami kenaikan seiring dengan bertambahnya waktu hingga mencapai titik setimbang. Grafik tersebut menjelaskan bahwa pada waktu tak hingga diperoleh nilai populasi nyamuk rentan terhadap waktu yaitu menuju titik 262,258 pada hari ke 7000 lebih. Pada kondisi tersebut sistem berada dalam kondisi stabil.

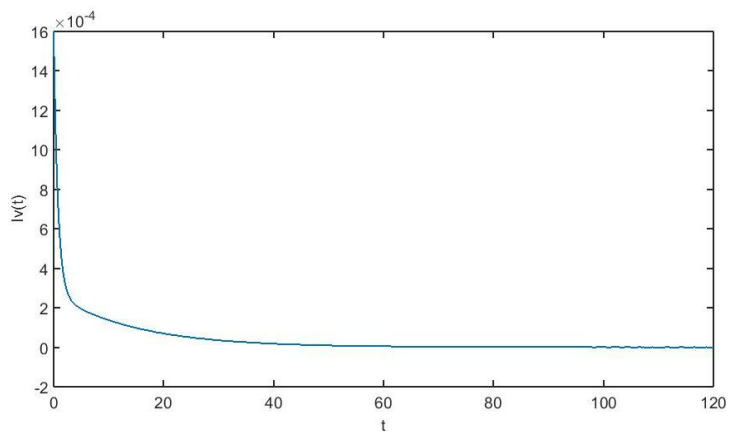

Gambar 6. Grafik Dinamika Populasi Nyamuk Terinfeksi $\left(I_{v}\right)$ dengan Pengaruh Fogging terhadap Waktu (t) saat Bebas Penyakit

Pada Gambar 6 menunjukkan bahwa jumlah nyamuk yang terinfeksi dengan nilai awal 0,0016 mengalami penurunan seiring bertambahnya waktu hingga mencapai titik setimbang. Grafik tersebut menjelaskan bahwa pada waktu tak hingga diperoleh jumlah populasi nyamuk terinfeksi terhadap waktu menuju titik nol pada hari ke 40 lebih dan tidak mengalami perubahan. Dengan kata lain jumlah populasi nyamuk yang terinfeksi dalam waktu yang lama penyakit demam berdarah akan menghilang.

\subsection{Simulalsi Model Matematika Penyebaran Demam Berdarah dengan Pengaruh Fogging saat Endemik}

Pada simulasi dengan kondisi endemik ini akan dibuat perbedaan dengan menaikkan nilai parameter $A_{v}$ menjadi 300 dengan mengambil nilai awal $S_{h}=904,491, I_{h}=0,0559, R_{h}=95,453$, $S_{v}=290,3167, I_{v}=0,0057$. Sedangkan untuk nilai parameter yang lain sama dengan nilai parameter untuk kondisi bebas penyakit pada Tabel 1. Sehingga diperoleh

$$
R_{0}=\frac{b^{2} \beta_{h} \beta_{v} A_{h} A_{v}}{\mu_{h} N_{h}^{2}\left(\mu_{v}+u\right)\left(\mu_{h}+\gamma_{h}\right)\left(\mu_{v}+u\right)}=1,105617092>1 .
$$




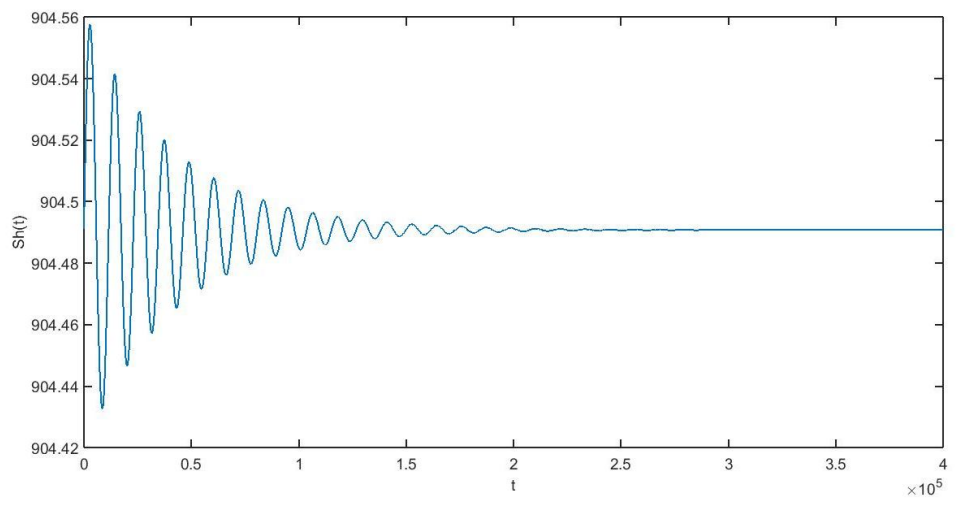

Gambar 7. Grafik Dinamika Populasi Manusia Rentan $\left(S_{h}\right)$ dengan Pengaruh Fogging terhadap Waktu (t) saat Endemik

Gambar 7 menjelaskan bahwa populasi manusia rentan dengan nilai awal 904,491 mengalami fluktuasi sampai 200000 hari. Kemudian seiring bertambahnya waktu akan menuju titik setimbang. Grafik ini menjelaskan bahwa pada waktu tak terhingga $(t \rightarrow \infty)$ diperoleh jumlah populasi manusia rentan terhadap waktu $S_{h}(t)$, menuju titik 904,4907575 pada hari ke 250000 lebih. Pada kondisi tersebut sistem dalam kondisi stabil.

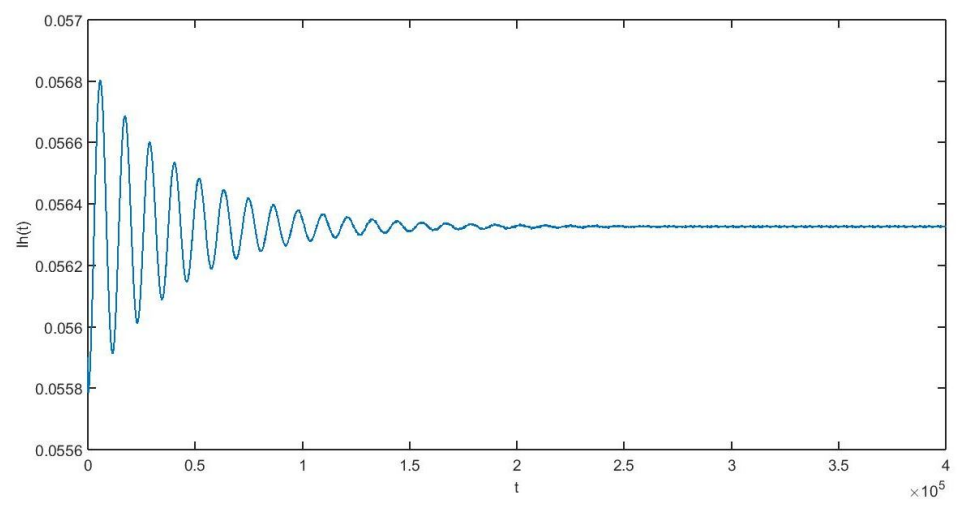

Gambar 8. Grafik Dinamika Populasi Manusia Terinfeksi $\left(I_{h}\right)$ dengan Pengaruh Fogging terhadap Waktu (t) saat Endemik

Gambar 8. menjelaskan bahwa populasi manusia terinfeksi dengan nilai awal 0,0559 mengalami flukstuasi sampai hari ke 200000. Kemudian seiring bertambahnya waktu akan menuju titik ketimbang. Grafik ini menjelaskan bahwa pada waktu tak terhingga $(t \rightarrow \infty)$ diperoleh jumlah populasi manusia terinfeksi terhadap waktu $I_{h}(t)$ menuju titik 0,05632627304 pada hari ke 250000 lebih. Pada kondisi tersebut sistem dalam kondisi stabil. Dengan kata lain bahwa penyakit demam berdarah tidak akan hilang dalam keadaan endemik. 
14 | Siti Windawati, Ali Shodiqin, Aurora Nur Aini - Analisis Kestabilan Model Matematika Penyebaran Penyakit Demam Berdarah ....

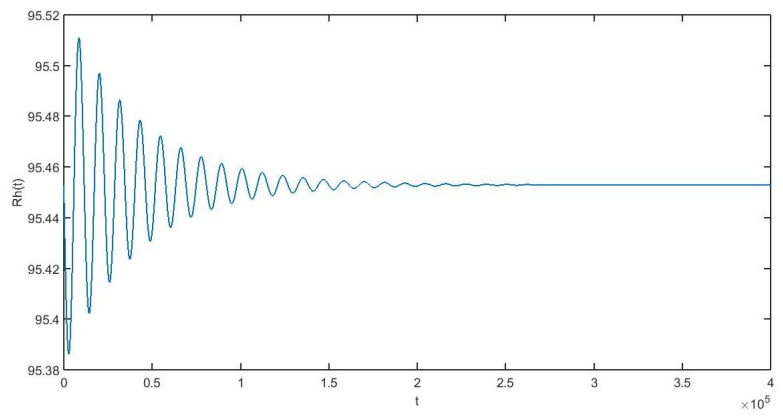

Gambar 9. Grafik Dinamika Populasi Manusia Sembuh $\left(\mathrm{R}_{\mathrm{h}}\right)$ dengan Pengaruh Fogging terhadap Waktu (t) saat Endemik

Gambar 9 menjelaskan bahwa populasi manusia sembuh dengan nilai awal 95,453 mengalami fluktuasi sampai hari ke 200000. Kemudian seiring bertambahnya waktu akan menuju ke titik setimbang. Grafik ini menjelaskan bahwa pada waktu tak terhingga $(t \rightarrow \infty)$ diperoleh jumlah populasi manusia sembuh terhadap waktu $R_{h}(t)$, munuju titik 95,45291627 pada hari ke 250000 lebih. Pada kondisi tersebut sistem dalam kondisi stabil.

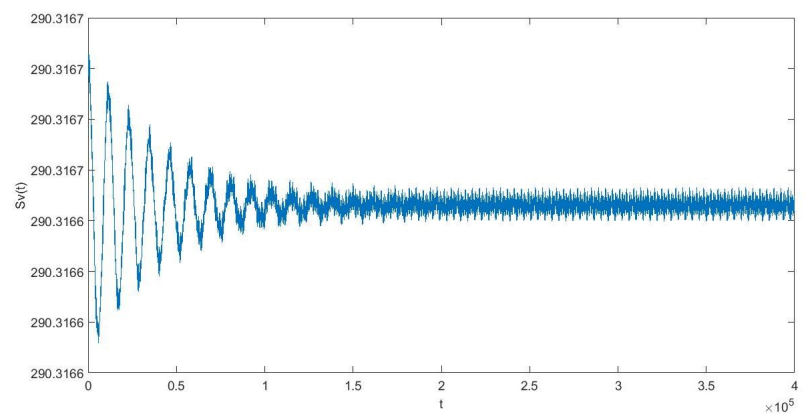

Gambar 10. Grafik Dinamika Populasi Nyamuk Rentan $\left(\mathrm{S}_{\mathrm{v}}\right)$ dengan Pengaruh Fogging terhadap Waktu (t) saat Endemik

Gambar 10 menjelaskan bahwa populasi nyamuk rentan dengan nilai awal 290,3167 mengalami fluktuasi sampai hari ke 100000. Kemudian setelah hari ke 100000 lebih keadaan populasi nyamuk rentan mengalami naik turun (osilasi) yang konstan di sekitar titik kesetimbangan. Pada populasi nyamuk rentan ini akan mencapai 290,3166463 pada saat $t \rightarrow \infty$ dan konstan pada titik tersebut. Osilasi di sekitar titik kesetimbangan yaitu gerakan bolak balik pada lintasan tertentu disekitar titik kesetimbangan.

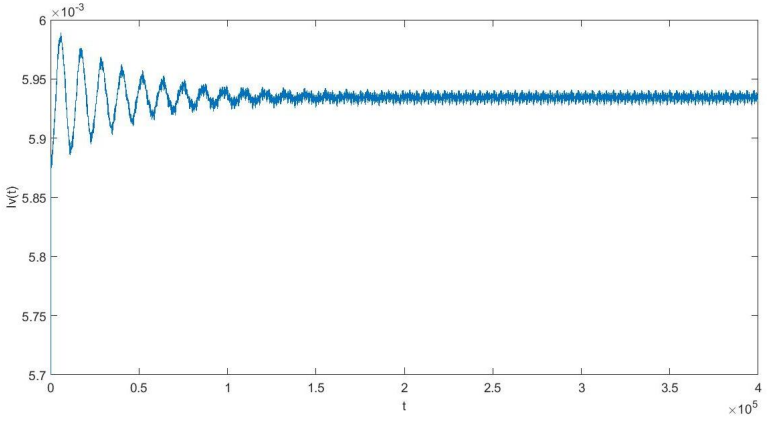

Gambar 11. Grafik Dinamika Populasi Nyamuk Terinfeksi $\left(\mathrm{I}_{\mathrm{v}}\right)$ dengan Pengaruh Fogging terhadap Waktu (t) saat Endemik 
Gambar 11 menjelaskan bahwa populasi nyamuk terinfeksi dengan nilai awal 0,0057 mengalami kenaikan dalam waktu singkat yang dilanjutkan dengan fluktuasi sampai hari ke 100000. Kemudian setelah hari ke 100000 lebih keadaan populasi nyamuk rentan mengalami naik turun (osilasi) yang konstan di sekitar titik kesetimbangan. Pada populasi nyamuk rentan ini akan mencapai 0,005934358556 pada saat $t \rightarrow \infty$ dan konstan pada titik tersebut.dengan kata lain penyakit tidak hilang dalam kondisi endemik.

\section{SIMPULAN}

Berdasarkan hasil penelitian analisis model penyebaran penyakit demam berdarah dengan pengaruh fogging diperoleh kesimpulan sebagai berikut.

1. Model matematika untuk penyebaran penyakit demam berdarah dengan pengaruh fogging berupa sistem persamaan diferensial sebagai berikut:

$$
\begin{aligned}
& \frac{d S_{h}}{d t}=A_{h}-\frac{b \beta_{h} S_{h} I_{v}}{N_{h}}-\mu_{h} S_{h} \\
& \frac{d I_{h}}{d t}=\frac{b \beta_{h} S_{h} I_{v}}{N_{h}}-\left(\mu_{h}+\gamma_{h}\right) I_{h} \\
& \frac{d R_{h}}{d t}=\gamma_{h} I_{h}-\mu_{h} R_{h} \\
& \frac{d S_{v}}{d t}=A_{v}-\frac{b \beta_{v} S_{v} I_{h}}{N_{h}}-\left(\mu_{v}+u\right) S_{v} \\
& \frac{d I_{v}}{d t}=\frac{b \beta_{v} S_{v} I_{h}}{N_{h}}-\left(\mu_{v}+u\right) I_{v}
\end{aligned}
$$

2. Berdasarkan hasil analisis diperoleh titik ekuilibrium bebas penyakit stabil asimtotik lokal jika bilangan reproduksi dasar $\left(R_{0}\right)$ kurang dari satu yaitu 0,998741. Sedangkan titik ekuilibrium endemik stabil asimtotik lokal jika bilangan reproduksi dasar lebih dari satu yaitu 1,105617092 .

3. Pada hasil simulasi diperoleh hasil pada kondisi bebas penyakit hanya ada populasi manusia rentan dan populasi nyamuk rentan sehingga penyakit akan menghilang dari populasi. Sedangkan pada keadaan endemik penyakit akan tetap ada dalam populasi manusia dan nyamuk.

\section{DAFTAR PUSTAKA}

Adi-Kusumo, F., Aini, A. N., \& Ridwan, M. (2014). Analysis of the dengue disease model with two virus strains. In AIP Conference Proceedings (Vol. 1587, No. 1, pp. 7-13). AIP.

Aguiar, M., \& Stollenwerk, N. (2017). Mathematical models of dengue fever epidemiology: multi-strain dynamics, immunological aspects associated to disease severity and vaccines. Communication in Biomathematical Sciences, 1(1), 1-12.

Arsin, A. A. (2013). Epidemiologi Demam Berdarah Dengue (DBD) di Indonesia. Makassar: Masagena Press. 
Aini, A. N., \& Shodiqin, A. (2014). Analisis Kestabilan dan Simulasi Model Penyakit Demam Berdarah Dengue (DBD). AKSIOMA: Jurnal Matematika dan Pendidikan Matematika, 5(2/septembe).

Bustamam, A., Aldila, D., \& Yuwanda, A. (2018). Understanding dengue control for short-and long-term intervention with a mathematical model approach. Journal of Applied Mathematics, 2018.

CNN Indonesia. (2019). Kasus Meningkat Indonesia Waspada DBD. https://m.cnnindonesia.com/gaya-hidup/20190131142925-255-365417/kasusmeningkat-indonesia-waspada-dbd/. Diakses 4 Agustus 2019 08:36.

Infodatin Pusat Data dan Informasi Kementerian Kesehatan RI. (2018). Situasi Penyakit Demam Berdarah di Indonesia Tahun 2017. http://www.depkes.go.id/download.php?file=download/pusdatin/infodatin/InfoDatinSituasi-Demam-Berdarah-Dengue.pdf. Diakses pada 31 Juli 2019 19:45.

Irianto, K. (2014). Epidemiologi Penyakit Menular dan Tidak Menular Panduan Klinis. Bandung: Alfabeta.

Masriadi. (2017). Epidemiologi Penyakit Menular. Depok: Rajawali Pers.

Side, S., Zaki, A., \& Sari, N. (2019). Analisis Model Matematika Penyebaran Demam Berdarah Dengue dengan Fungsi Lyapunov. Journal of Mathematics, Computations, and Statistics, 1(2), 125-141. 